\title{
Qualitative Management Accounting Research in QRAM: Some Reflections
}

John Burns

University of Exeter, UK

j.e.burns@exeter.ac.uk

\section{Brief Biography:}

John has been at Exeter Business School since 2010, following previous spells working at Dundee, Colorado, and Manchester. He is a past Associate Editor for Management Accounting Research (2002-13) and Accounting and Business Research (2005-09), and has been a member of CIMA's Research Board since 2002. He is co- founder of the 'European Network for Research of Organisational and Accounting Change' (ENROAC), and a Visiting Professor at WHU Otto Beisheim School of Management (Germany) and University College Dublin (Ireland).

Acknowledgements: The paper is premised on personal reflection and opinion, and there is only myself to blame for any errors. I would like to thank Stephen Jollands, Kim Soin and Deryl Northcott for helpful comments on an early draft.

\section{ABSTRACT:}

Purpose: This paper offers a brief personal reflection upon, and celebrates, the $10^{\text {th }}$ anniversary of Qualitative Research in Accounting \& Management (QRAM). More specifically, I highlight the journal's contributions towards advancing qualitative management accounting research over the last decade, and I suggest possible future avenues.

Design/Methodology/Approach: This is a relatively short paper, and mainly constitutes a review of qualitative management accounting articles published in the first ten years of QRAMs publishing life, plus some personal reflection and suggestions for future directions.

Findings: I celebrate the impressive achievements of QRAMs founding editors, and I am encouraged to offer my personal views on how the journal might excel further in years to come.

Research Implications: Although the piece is primarily personal reflection, there is hopefully some food for thought with regards to fruitful directions in tomorrow's qualitative management accounting research. In particular, arguments are made for more undertaking of processual qualitative research and also for more targeted focus on the connections between 
management accounting and other relevant disciplines such as management and organisation studies.

Practical Implications: The paper offers no practical implications as such, but does discuss, and in fact heeds some caution against, the apparent trend of (possibly too uncritically) seeking to tease out practical implications from qualitative management accounting research.

Social Implications: Again, while this paper offers no specific discussion on its social implications, I would add that any qualitative management accounting research paper inherently carries at least some implications for society; management accounting and the wider society are continually intertwined through time.

Originality/Value: I would not claim that there is much that is original in this short piece most of what is offered simply gathers others' past contributions. But hopefully there will be some value in the ideas offered with regards to the exciting future ahead for qualitative management accounting research in QRAM.

Keywords: Management accounting; Qualitative research; Processual research; Philosophical underpinnings; Theory; Practical relevance

Article Classification: Viewpoint 


\section{Introduction}

I was delighted to be asked to write a brief reflection upon and celebrate the $10^{\text {th }}$ anniversary of Qualitative Research in Accounting \& Management (QRAM). The journal has been an outstanding success, especially in light of how relatively short ten years constitutes in a journal life, and also when considering the number of more established competitor journals in the field. My task was to 'offer reflections on advances in qualitative management accounting research over the last decade', and to suggest possible future interests.

\section{A qualitative specialist: but much more to be learned}

Already, QRAM has significantly extended our knowledge of management accounting practice and its contemporary developments. For instance, we have learned much through articles that have surveyed new management accounting innovations in general (Zawawi et al., 2010), and via those articles that are more specifically focused on particular innovations such as activity-based costing (Agndal and Nilsson, 2007), the balanced scorecard (Länsiluoto and Järvenpää, 2008), target costing (Everaert et al., 2006) and six-sigma (Busco and Scapens, 2011).

The first decade of publications in QRAM have also offered new insights into the broader contexts within which management accounting evolves, particularly reflecting the 'management' dimension to QRAM's net. For instance, but by no means exhaustive, we have been presented with articles that have explored management accounting in the context of the global financial crisis (Baldvinsdottir et al., 2010), outsourcing (Elharidy et al., 2013), new product development (Akroyd and Maguire, 2011), and public sector management trends (Silva and Ferreira, 2010). I would argue that this particular aspect of QRAM's contribution to date - exploration and conceptualisation of management accounting in its broader and temporal contexts, especially its interface with management - is something that the journal should promote even further in the future (see later, also).

But, the most distinguishing feature of $Q R A M$ is obviously its alignment to qualitative research design, a brave direction taken by the founding editors in an accounting discipline that overall is dominated by quantitative research. In its first ten years, QRAM has extended our knowledge of what it means to be undertaking management accounting research that is qualitative in nature, the possible research tools, and why qualitative research matters (Baxter and Chua, 2008; Chapman, 2008; Lillis, 2008; Vaivio, 2008). There is, however, much still to be learned, and QRAM authors should continue to develop this understanding. 
A large part of the reason why quantitative management accounting research is so popular and dominant (particularly outside of Europe) is that its methods are generally regarded as being structured, transparent and easy-to-follow. In comparison, the methods normally utilised in qualitative management accounting research are regarded by some as being less clear and under-developed. This situation dents the credibility and persuasiveness of qualitative research in the mostly applied-oriented management accounting research community.

However, it is an opportune time for $Q R A M$ to promote and publish new contributions to the debate on why and how qualitative research is important. In other key and closely related academic disciplines, in particular management and organisation studies, qualitative research is in the ascendancy and experiencing a 'coming of age' (Bansal and Corely, 2011). There seems little reason why QRAM outputs cannot contribute towards this momentum. Indeed, this would seem paramount, and as will be expanded below, future QRAM authors could specifically aim to connect with, and contribute towards, knowledge outside of management accounting per se. In particular, it would seem reasonable to suggest that in most qualitative management accounting research, including that which is published in QRAM, too little space is allocated to discussion of the research methods used (Condie, 2012; Grafton et al., 2011; Qu and Durnay, 2011) ; there is most definitely room for advancing our knowledge in this respect. Not unrelated, I would argue that there is also too little attention given to the philosophical underpinnings of qualitative management accounting research (de Loo and Lowe, 2011), although $Q R A M$ has probably given more publication pages to thoughtful methodology papers (e.g., Hansen, 2011) than most accounting journals over the past ten years.

When I began a PhD in 1993, I probably would not have recognised 'qualitative research' if it had slapped me in the face. Until that stage, my academic experience had been as an economics student, enduring neoclassical theory and statistical modelling, so 'qualitative' never really entered my vocabulary. My awareness and 'placing' of qualitative research began when my PhD supervisor tasked me with investigating some of the philosophical foundations of management accounting research. So, I immersed myself into such classics as Tomkins and Groves (1983), Chua (1986) and Hopper and Powell (1995), to name a few. This helped me to identify my qualitative leanings, but it also did much more.

This early-stage philosophical grounding guided me through a maze of complicated phenomena such as ontology, epistemology, methodology and methods. At first meeting, the 'ologies' were an uncomfortable addition to my life - I was reluctantly questioning things that I had taken for granted in my every-day life. Of course, twenty years on, and I better understand the necessity of considering the philosophical underpinnings before engaging in any research. But, more to the point, my sense is that as qualitative researchers of 
management accounting, we have a tendency (myself included) to understate and marginalise the philosophical foundations of our work.

In most qualitative management accounting research, our main contribution tends to be geared more towards our empirical (usually case-based) analyses and our theoretical infusion. Conversely, the ontological, epistemological and methodological aspects of our research, as well as our adopted research methods, frequently receive far less attention. This, however, is not necessarily due to a lack of appetite amongst researchers to engage in such work, but may well have more to do with editors, reviewers and/or publishers. Whatever the main drivers, I would argue that this is not a sensible way to carry out our research in the future, and such marginalisation will likely slow down any progress in connecting our management accounting outputs to broader disciplines such as management and organisation studies. So, I think there is opportunity for more explicit articulation of the philosophical bases in qualitative management accounting research.

\section{Processual (qualitative) management accounting research}

Common amongst QRAM's articles, particularly over the last five years, is a focus on the development and change of management accounting practices over time (Abrahamsson and Gerdin, 2006; Akroyd and Maguire, 2011; Busco and Scapens, 2011; Elharidy et al., 2013; Hoque and Chia, 2012; Länsiluoto and Järvenpää, 2008; Moilanen, 2008; Rautiainen and Scapens, 2013; Sánchez-Rodriguez and Spraakman, 2012). I can associate with this interest in studying management accounting phenomena as unfolding process over time, and it is a direction that I firmly believe that $Q R A M$ should continue to promote.

The study of how and why phenomena becomes what it is (or is not) over time, is not entirely new to management accounting research (e.g., see Hopwood, 1987), but has tended to fluctuate in popularity over the years, and lacks a unified programme across management accounting and other disciplines where it can nevertheless be found. Process-oriented research focuses attention on how and why organisational phenomena emerge, settle, change and unfold over time. It thus concerns itself with the empirical study of organisational evolution, and adopts theories that explicitly incorporate temporality (i.e., where time is taken seriously) as a key element of subsequent explanation and understanding. ${ }^{1}$

Temporality matters significantly in organisational life, including management accounting, yet the literature continues to be dominated by 'static' approaches that elevate variance

\footnotetext{
${ }_{1}$ Processual research can be quantitative in nature (e.g., where change between steady states is studied over time, via statistical methods), but most processual research in the management and organisational disciplines tends to be qualitative (Langley et al., 2013).
} 
questioning to identify co-variation among dependent and independent variables, and which generally espouse to 'know-what' modelling of so-called (optimal) 'best' organisational practice. In contrast, process research incorporates notions of causality as constituted by sequences of interconnected events rather than through abstract correlations. Thus, such an approach promises to extend 'know-how' theorising.

Process thinking acknowledges at the outset that an organisational field is complex and, in an era when we witness many organisations immersed in a continuous flow of uncertainty, unpredictability and ongoing change, it would seem sensible to pursue new conceptualisation which assumes that 'everything flows'. This means questioning the predominance of timeless concepts across the management accounting literature, and of fixed and 'untouchable' taxonomies, as well as moving outside the common assumption of linear causality in a world that is continuously on the move and evolving.

Importantly, processual curiosity is gaining significant support amongst eminent scholars of the management and organisation disciplines. For example, recently there was a special issue of Academy of Management Journal on 'process studies' (Langley et al., 2013), and numerous other recent processual contributions have been published in such journals as Organisation Studies and Organization Science, as well as major conferences being dedicated recently to the process-oriented theme. Thus, this would also seem a good time to develop (qualitative) processual research in QRAM. It is widely acknowledged that such a programme faces considerable challenges, not least a fundamental requirement to develop and extend its methodological and theoretical roots, as well as to identify more (and better) research methods for undertaking process research. Even so, it most certainly seems to be a development that the $Q R A M$ authorship could contribute towards.

\section{Theory in qualitative management accounting research}

QRAM has no theoretical bias, and over the first ten years of its publishing life various authors have adopted an array of theories, most commonly as a lens to assist the interpretation of longitudinal case studies. The theories that have been used to date, but in no particular order, include: institutional theory (Abrahamsson and Gerdin, 2006; Jazayeri et al., 2011; Moilanen, 2008; Rautiainen and Scapens, 2013; Ribeiro and Scapens, 2006), actor-network theory (Hansen, 2011; Rautiainen and Scapens, 2013; Voselman, 2012), structuration theory (Busco and Scapens, 2011), Foucault's govenmentality (Jakobsen, 2012), Schein's theory of culture (Busco and Scapens, 2011), transaction cost economics (Vosselman, 2012) and contingency theory (Porporato, 2009). 
Some articles in QRAM have also combined more than one theoretical approach in an attempt to draw out richer analysis and interpretation of empirical observations - e.g., Rautiainen and Scapens' (2013) combination of actor-network theory and new institutional sociology, Vosselman's (2012) fusion of transaction cost economics and actor-network theory, and Busco and Scapens' (2011) combined use of Schein's culture theory and Giddens' structuration approach.

However, while we have seen explicit cases being made for more theoretical pluralism in qualitative management accounting research (van der Meer-Kooistra and Vosselman, 2012), other authors have warned against or at least heeded caution at pluralist tendencies, and especially blending distinct theories, normally on grounds that such strategy erroneously undermines the fundamental philosophical differences amongst individual theoretical frames (de Loo and Lowe, 2011; Hansen, 2011).

I have sympathy with this caution, although I admit personally to being 'guilty' of combining different theoretical frameworks in my own past research. The issue, I would argue, relates to earlier discussion (above) concerning a need to extend and deepen our understanding of the philosophical underpinnings of qualitative management accounting research. Whereas it is probably fair to say that most works in the qualitative management accounting field devote relatively more time and space to theory and theoretical interpretations of our empirical data, we should probably consider relatively more attention in the future to our philosophical grounding. I would argue that our choice of theory (or theories) should be influenced by our philosophical standpoint - i.e., our ontological assumptions, epistemology and methodology. Yet, we do seem (at least it appears to me) to sometimes get a little carried away with our concern for theory per se, at the expense of overlooking the philosophical dimensions of (and research methods implicated in) our work. Maybe it is an opportune time for QRAM and its authors to spend a bit of time 'going back to basics'?

\section{The practical relevance of qualitative management accounting research}

Another theme that has commanded not-insignificant attention in QRAMs early years is the practical-relevance of qualitative management accounting research. Indeed, there was recently a special issue dedicated to this particular theme (ter Bogt and van Helden, 2012). While hardly new, the question of 'relevance' holds an important position in qualitative management accounting research; some argue because it is fundamentally an 'applied discipline' (Scapens, 2012; van der Meer-Kooistra and Vosselman, 2012).

Numerous QRAM articles have made useful connection(s) to practice, and several authors have been quite explicit about the need for there to be a greater practical 'impact' in 
qualitative management accounting research (Scapens, 2012; Seal, 2012). However, notwithstanding that making connection to practice is important, I would hope that QRAM does not become too sucked into the practical-relevance debate and, in particular, that it maintains primary focus on achieving academic rigour, especially theoretical development (Chapman, 2012; Lapsley, 2012).

There are many pressures upon today's academics that make it more difficult not to pay at least some attention towards the issue of practical-relevance. For instance, through rankings, we are experiencing significant change in the perceived value attached to qualitative (and other) management accounting research - furthermore, I would expect that the positive correlation between practical relevance and rankings will become even more obvious. In addition, in the UK for instance, that (depleted) public funding that still exists is increasingly expected to deliver 'impact', which effectively means having an influence on business-related policies and practice. Possible new avenues for research funding include partnerships with organisations, some argue via 'interventionist' research (Jönsson, 2010; Scapens, 2012; Westin and Roberts, 2010) where practitioners and researchers cooperate to provide solutions to practical problems. Another source of research funding in our area has traditionally been the accountancy professional bodies, but again such funding always comes with a clear requirement to 'deliver to practice'.

However, as qualitative management accounting researchers, how far should we elevate this connecting-with-practice? For what it's worth, I would go along with those who argue for commitment towards a primary focus on academic rigour and theoretical development, and that we must not stifle academic curiosity (Chapman, 2012). I particularly feel uneasy when I am alerted to yet more rankings that are grounded in contestable practical relevance, as increasingly seems to happen nowadays, when measuring academic faculty's research 'impact'. But also, if I understand correctly the terminology being used, I do not entirely buy into the rather narrow assumption of management accounting as an 'applied discipline' and there is a significant strand of qualitative management accounting research that affords far less priority towards practical relevance. More specifically, there are numerous scholars in the qualitative management accounting research community who generally use management accounting as a 'vehicle' to explore and theorise a particular organisational practice in its broader setting. To these researchers, their focus constitutes much more than practical, but rather broad understanding, explanation and theorisation of inter- and intra-organisational processes in their extended context.

Arguments for a (perceived) need to pursue practice-relevance and academic rigour, coexisting and without tension, are becoming more popular (van Helden and Northcott, 2010; ter Bogt and van Helden, 2012; Scapens, 2012). Some of the drivers at play have already been mentioned (e.g., shrinkage in public and professional research funding), but maybe there is 
another key influence. In this regard, it is interesting to read the editors'2 commentaries in QRAM's recent debate on practical-relevance. The common view was "that in management accounting research, practical-relevance and academic rigour are easily combinable" (ter Bogt and van Helden, 2012, p. 268), and not a single editor in that special issue explicitly stated that academic rigour (including theoretical development) was the priority. ${ }^{3}$

\section{The 'other' dimension to $Q R A M$}

QRAM is part of a dwindling number of journals with a management accounting focus that is not dominated by quantitative research design. This minority positioning should be viewed as an opening for new opportunities; QRAM should steam ahead and continue to advance discipline knowledge via its specific approach. My sense is that the journal has exciting opportunities to firmly establish itself in areas that few accounting journals connect with. An example in this respect has already been discussed, namely the development of processual (qualitative) management accounting research. In addition, I would argue that the QRAM authorship has an opportunity to extend its contribution(s) outside of management accounting per se, possibly much farther than other competing journals do.

A large part of $Q R A M$ s strength and future capability in comparison to other journals that attend to management accounting issues is indeed its specificity on qualitative research. As mentioned already, this speciality can and should be stretched further. A key objective for tomorrow's QRAM authors should be extending our knowledge of why and how we undertake qualitative research, the ramifications of which can reach beyond management accounting literature. Alongside this, QRAMs explicit focus on the interface between management and accounting phenomena is something that I believe can also be extended. Most of the dominant (and largely quantitative) management accounting literature has tendencies to isolate its subject from broader dimensions, and there is every reason for QRAM not to follow this trend.

In a related way, it is also noticeable how few management accounting articles are published in management (-related) journals. Without a detailed discussion of why this might be the case, it is a situation that baffles me since management accounting is at the hub of so much that unfolds in organisational life and in the day-to-day routines of managers. For instance, it is quite conceivable to think management accounting would be a key ingredient to

\footnotetext{
2 In this special issue of $Q R A M$ (2012, Vol. 9, No. 3), commentaries are provided by the editors, at that time, of: Accounting, Auditing \& Accountability Journal; Abacus; Accounting, Organizations and Society; Critical Perspectives on Accounting; European Accounting Review; Financial Accountability and Management; Journal of Management Accounting Research; and Management Accounting Research.

3 The editor of Accounting, Organizations and Society was probably closest to emphasising academic contribution over practical-relevance.
} 
investigations of such topical issues as sustainable development, strategic management, risk management, and new product development. It would seem sensible therefore for QRAMs community to promote itself, and for the journal to become increasingly connected to the broader academic management field. Not least, a recent trend amongst management journals ${ }^{4}$ is in fact a noticeable increase in (mostly qualitative) processual studies (Langley et al., 2013).

\section{Concluding comments: be bold, and onwards!}

For most of the readers of this article, there's something about qualitative research that 'just makes sense', even if the majority of management accounting researchers seem to view our approach as somewhat 'fluffy' and unstructured. To us, qualitative research design draws out rich understandings of our empirical observations, explains and helps to conceptualise the ways of the world as they unfold through time:

$[\ldots]$ researchers who feel that the quantitative approach offers a spurious accuracy $[\ldots]$ uncomfortable with the apparent precision with which rather soft variables are said to be captured by quantification [...] enjoy dealing with messy, complex problems in a relatively unstructured way and also in a way that tests their ability to offer nuanced interpretations of phenomena [...] offering deeper insights into social investigation (Lapsley, 2012, p. 291)

The founding editors of $Q R A M$, supported by innovative publishers, were extremely bold when they founded the journal. It was always going to be a difficult challenge, a struggle, for QRAM to establish itself in such a quants-dominated field. But, with hard work and sound promotional effort, the editors and publishers of QRAM have managed rather rapidly to establish the journal to its position of impressive respectability, in particular across Europe and Australasia, and the momentum must continue. QRAM can, and should, build on its qualitative uniqueness in the management accounting area.

There is no denying the various pressures that editors and publishers are under to maintain their portfolio of academic journals, and particularly the methodological nature and 'selling point' of such journals. But, as accountable academics, we are now more dependent than ever on the continuing existence of publication outlets that will accept, disseminate and promote our work. Regrettably, in management accounting, the qualitative research 'net' threatens to shrink ever more, hence the utmost significance of specialist journals such as QRAM. The wider environmental trends such as depleting research funds and the 'impact' phenomena also exert more pressure on qualitative scholars, particularly as their research tends to need time and usually does not seek practical solutions. It is a concern, there is no

\footnotetext{
${ }^{4}$ E.g., Academy of Management Journal, Organization Studies, Organization Science.
} 
doubting that, but I have every confidence that we will be celebrating another very successful decade for QRAM in 2023.

\section{References}

Abrahamsson, G. and Gerdin, J. (2006), "Exploiting institutional contradictions: the role of management accounting in continuous improvement implementation", Qualitative Research in Accounting \& Management, Vol. 3, No. 2, pp. 126-144.

Agndal, H. and Nilsson, U. (2007), "Activity-based costing: effects of long-term buyer-supplier relationships", Qualitative Research in Accounting \& Management, Vol. 4, No. 3, pp. 222-245.

Akroyd, C. and Maguire, W. (2011), "The roles of management control in a product development setting", Qualitative Research in Accounting \& Management, Vol. 8, No. 3, pp. 212-237.

Baldvinsdottir, G., Burns, J., Nørreklit, H., and Scapens, R. (2010), "Professional accounting media: accountants handing over control to the system", Qualitative Research in Accounting \& Management, Vol. 7, No. 3, pp. 395-414.

Bansal, P. and Corely, K. (2011), "The coming of age for qualitative research: embracing the diversity of qualitative methods", Academy of Management Journal, Vol. 52, No. 2, pp. 233237.

Baxter, J. and Chua, W. F. (2008), "The field researcher as author-writer", Qualitative Research in Accounting \& Management, Vol. 5, No. 2, pp. 101-121.

Bogt, H. ter and Helden, G. J. van (2012), "The practical relevance of management accounting research and the role of qualitative methods therein: the debate continues", Qualitative Research in Accounting \& Management, Vol. 9, No. 3, pp. 265-295.

Busco, C. and Scapens, R.W. (2011), "Management accounting systems and organisational culture: interpreting their linkages and processes of change", Qualitative Research in Accounting \& Management, Vol. 8, No. 4, pp. 320-357.

Chapman, C.S. (2008), "We are not alone: qualitative management accounting research rationale, pitfalls and potential" Qualitative Research in Accounting \& Management, Vol. 5, No. 3, pp. 247-52.

Chua, W.F. (1986), "Radical developments in accounting thought", Accounting Review, Vol. 61, No. 4, pp. 601-632.

Condie, J. (2012), "Beyond rationalisations: improving interview data quality", Qualitative Research in Accounting \& Management, Vol. 9, No. 2, pp. 168-193.

Elharidy, A.M., Nicholson, B., and Scapens, R. (2013), "The embeddedness of accounting outsourcing relationships", Qualitative Research in Accounting \& Management, Vol. 10, No. 1 , pp. 60-77.

Everaert, P., Loosveld, S., Acker, T.V., Schollier, M., and Sarens, G. (2006), "Characteristics of target costing: theoretical and field study perspectives", Qualitative Research in Accounting \& Management, Vol. 3, No. 3, pp. 236-263.

Grafton, J., Lillis, A. and Mahama, H. (2011), "Mixed methods research in accounting", Qualitative Research in Accounting \& Management, Vol. 8, No. 1, pp. 5-21. 
Hansen, A. (2011), "Relating performative and ostensive management accounting research: reflections on case study methodology", Qualitative Research in Accounting \& Management, Vol. 8, No. 2, pp. 108-138.

Helden, G. J. van and Northcott, D. (2010), "Examining the practical relevance of public sector management accounting research", Financial Accountability and Management, Vol. 26, No. 2, pp.213-240.

Hopper, T. and Powell, A. (1995), "Making sense of research into organizational and social aspects of management accounting: a review of its underlying assumptions", Journal of Management Studies, Vol. 22, No. 5, pp. 429-465.

Hopwood, A. (1987), "The archeology of accounting systems", Accounting, Organizations and Society, Vol 12, No. 3, pp. 207-234.

Hoque, Z. and Chia, M. (2012), "Competitive forces and the levers of control framework in a manufacturing setting: a tale of a multinational subsidiary", Qualitative Research in Accounting \& Management, Vol. 9, No. 2, pp. 123-145.

Jazayeri, M., Wickramasinghe, D., and Gooneratne, T. (2011), "Convergence versus divergence of performance measurement systems: lessons from spatial variations", Qualitative Research in Accounting \& Management, Vol. 8, No. 3, pp. 292-314.

Jakobsen, M. (2012), "Intra-organisational management accounting for inter-organisational control during negotiation processes", Qualitative Research in Accounting \& Management, Vol. 9, No. 2, pp. 96-122.

Jönsson, S. (2010), "Interventionism - an approach for the future?", Qualitative Research in Accounting \& Management, Vol. 7, No. 1, pp. 124-134.

Langley, A., Smallman, C., Tsoukas, H. and Van de Ven, A.H. (2013) "Process studies of change in organization and management: unveiling temporality, activity and flow", Academy of Management Journal, Vol. 56, No. 1, pp.1-13.

Lapsley, I. (2012), "Financial Accountability and Management", Qualitative Research in Accounting \& Management, Vol. 9, No. 3., pp.

Länsiluoto, A. and Järvenpää, M. (2008), "Environmental and performance management forces: integrating 'greenness' into balanced scorecard", Qualitative Research in Accounting \& Management, Vol. 5, No. 3, pp. 184-206.

Lillis, A. (2008), "Qualitative management accounting research: rationale, pitfalls and potential: a comment on Vaivio (2008)", Qualitative Research in Accounting \& Management, Vol. 5, No. 3, pp. 239-246.

De Loo, I. and Lowe, A. (2011), "Mixed methods research: don't: 'just do it", Qualitative Research in Accounting \& Management, Vol. 8, No. 1, pp. 22-38.

Meer-Kooistra, J. van der and Vosselman, E. (2012), "Resarch paradigms, theoretical pluralism and the practical relevance of management accounting knowledge", Qualitative Research in Accounting \& Management, Vol. 9, No. 3, pp. 245-254.

Moilanen, S. (2008), "The role of accounting in the management control system: a case study of a family-led firm", Qualitative Research in Accounting \& Management, Vol. 5, No. 3, pp. 165-183.

Porporato, M. (2009), "Timing and drivers of management control systems in joint ventures: the effect on JV survival", Qualitative Research in Accounting \& Management, Vol. 6, No. 4, pp. 247-274. 
Qu, S. and Durnay, J. (2011), "The qualitative research interview", Qualitative Research in Accounting \& Management, Vol. 8, No. 3, pp. 238-264.

Rautiainen, A. and Scapens, R.W. (2013), "Path-dependencies, constrained transformations and dynamic agency: an accounting case study informed by both ANT and NIS", Qualitative Research in Accounting \& Management, Vol. 10, No. 2, pp. 100-126.

Ribeiro, J.A. and Scapens, R. W. (2006), "Institutional theories in management accounting change: contributions, issues and paths for development", Qualitative Research in Accounting \& Management, Vol. 3, No. 2, pp. 94-111.

Sánchez-Rodriguez, C. and Spraakman, G. (2012), "ERP systems and management accounting: a multiple case study", Qualitative Research in Accounting \& Management, Vol. 9, No. 4, pp. 398-414.

Scapens, (2012), "How important is practice-relevant management accounting research?", Qualitative Research in Accounting \& Management, Vol. 9, No. 3., pp.

Seal, W. (2012), "Some proposals for impactful management control research", Qualitative Research in Accounting \& Management, Vol. 9, No. 3, pp. 228-244.

Silva, P. and Ferreira, A. (2010), "Performance management in primary healthcare services: evidence from a field study", Qualitative Research in Accounting \& Management, Vol. 7, No. 4, pp. 424-449.

Tomkins, C. and Groves, R. (1983), "The everyday accountant and researching his reality", Accounting, Organizations and Society, Vol. 8, No. 4, pp. 361-374.

Vaivio, J. (2008), "Qualitative management accounting research: rationale, pitfalls and potential", Qualitative Research in Accounting \& Management, Vol. 5, No. 1, pp. 64-86.

Vosselman, E. (2012), "Approaching control in interfirm transactional relationships: contrasting and connecting a transaction cost economics perspective with an actor-network theory perspective", Qualitative Research in Accounting \& Management, Vol. 9, No. 1, pp. 420.

Westin, O. and Roberts, H. (2010), "Interventionist research - the puberty years: an introduction to the special issue", Qualitative Research in Accounting \& Management, Vol. 7, No. 1, pp. 5-12.

Zawawi, N.H.M., Terengganu, K. and Hoque, Z. (2010), "Research in management accounting innovations: an overview of its recent development", Qualitative Research in Accounting \& Management, Vol. 7, No. 4, pp. 505-568. 